\title{
PEMBERIAN PUPUK HIJAU DAN MOL TERHADAP PERTUMBUHAN DAN HASIL TANAMAN KACANG TANAH (ARACHIS HYPOGEAE L) IWAN UMBU SIWA BALLA ${ }^{1)}$, I MADE SUNANTRA ${ }^{2), ~ W A W A N ~ A P Z A N I ~}{ }^{3)}$ \\ 1). Alumni, ${ }^{2,3)}$ Dosen Fakultas Pertanian Universitas 45 Mataram e-mail :2)sunantra..spt@gmail.com, ${ }^{3)}$ apzaniwawan@gmail.com
}

\section{ABSTRAK}

Tujuan penelitian ini adalah untuk mengetahui pengaruh pemberian pupuk hijau dan mikro organisma lokal (MOL) terhadap pertumbuhan dan hasil Tanaman Kacang Tanah. Penelitian ini menggunakan metode eksperimental dengan Rancangan Acak Lengkap yang terdiri dari 2 faktor yaitu pupuk hijau dan mikro organisma lokal. Perlakuan terdiri dari tanpa Pupuk, pemupukan dengan pupuk hijau dari daun gamal, turi, chlotalaria dan daun Chromolaena. Kemudian ada yang tidak menggunakan MOL dan menggunakan MOL. Keduanya dikombinasikan hingga menjadi 10 perlakuan.

Hasil penelitian menunjukkan pupuk Hijau dan Mikro Organisma Lokal mempengaruhi hasil tanaman kacang tanah secara signifikan. Perlakuan Cromolaena menunjukkan peningkatan hasil sebesar 31,37\% selanjutnya diikuti oleh daun Turi $27,45 \%$, daun Gamal 15,69\% dan Chlotalaria $11,76 \%$. Selanjutnya perlakuan Mikro Organisma Lokal meningkatkan hasil sebesar 14,90\%.

Kata Kunci : Pupuk hijau, MOL, pertumbuhan dan hasil, tanaman kacang tanah

\section{ABSTRACT}

The purpose of this study is to determine the effect of local green manure and micro organism (MOL) on the growth and yield of Peanut Plants. This study uses an experimental method with a Completely Randomized Design consisting of 2 factors, namely green manure and local micro organisms. The treatment consisted of no fertilizer, fertilizing with green fertilizer from gamal leaves, turi, chlotalaria and Chromolaena leaves. Then there are those who do not use MOL and use MOL. Both are combined to become 10 treatments.

The results showed that Green and Micro Local Organisms fertilizers significantly affected peanut yield. Cromolaena treatment showed an increase in yield of $31.37 \%$, followed by Turi leaves $27.45 \%$, Gamal leaves $15.69 \%$ and Chlotalaria $11.76 \%$. Furthermore, the treatment of local micro organisms increases the yield by $14.90 \%$.

Keywords: Green manure, MOL, growth and yield, peanut plants

\section{PENDAHULUAN}

\section{Latar Belakang}

Kacang tanah (Arachis hypogaea L.) merupakan tanaman legum terpenting setelah kedelai yang memiliki peran pada pangan nasional sebagai sumber protein dan minyak nabati. Sebagai bahan pangan dan makanan yang bergizi tinggi, kacang tanah mengandung lemak $40-50 \%$, protein $27 \%$, karbohidrat dan vitamin (Suprapto, 2001). Dewasa ini olahan kacang tanah sangat berkembang pesat bahkan telah ada industri besar seperti kacang tanah oven merek Dua Kelinci dan banyak lagi olahan kacang lainnya, sehingga kebutuhan akan kacang tanah terus meningkat.

Produksi kacang tanah ditingkat petani masih di bawah 1,0 ton/ha padahal potensinya dapat mencapai lebih dari 4 ton/ha (Tim Bina Karya Tani, 2014). Mengingat masih rendahnya hasil dan kebutuhan pasar akan kacang tanah untuk industri sangat banyak, maka perlu dilakukan usaha- usaha yang serius untuk 
meningkatkan hasil. Dewasa ini banyak cara yang dilakukan untuk meningkatkan hasil kacang tanah salah satunya melalui pemupukan.

Pemakaian pupuk anorganik telah terbukti meningkatkan hasil dari waktu ke waktu, namun tanpa disadari bahwa penggunaan pupuk organis yang secara terus menerus tentu berdampak yasang tidak baik bagi sifat fisik, kimia, dan biologi tanah (Parnata, 2004). Untuk menanggulangi sifat negatif ini digunakanlah pupuk organik sebagai solusi pemecahannya.

Pupuk organik adalah pupuk dari hasil pelapukan mahluk hidup seperrti flora dan fauna yang dapat berbentuk padat atau cair dan mampu memperbaiki sifat fisik, kimia, dan biologi tanah. Pupuk ini memiliki kelebihan dibanding dengan pupuk an organik, di antaranya adalah : a). Berfungsi sebagai granulator sehingga dapat memperbaiki struktur dan sifat fisik tanah, b). Daya serap tanah terhadap air meningkat dengan pemberian pupuk organik karena dapat mengikat air lebih banyak dan lebih lama, c). Meningkatkan kondisi kehidupan mikrobia di dalam tanah,d). Mengandung unsur hara makro maupun mokro, e). Meningkatkan Kapasitas Kation (KTK) tanah.

Pupuk hijau adalah salah satu pupuk organik yang merupakan keseluruhan tanaman hijau maupun bagian dari tanaman seperti daun, sisa batang dan tunggul akar. Tanaman yang cocok dijadikan pupuk hijau adalah daun Clotalaria, Gamal dan Turi. Menurut (Jusuf, 2006) Pemberian pupuk hijau dari daun gamal memberikan pengaruh terhadap ketesediaan $\mathrm{N}, \mathrm{P}, \mathrm{Mg}$ serta memperbaiki $\mathrm{pH}$ tanah, sedangkan pupuk hijau dari daun Clotalaria, daun Chromolaena dan Turi (Sesbania grandiflora) mengandung banyak nitrogen serta unsur hara penting lainnya yang dibutuhkan oleh tanaman. Namun kelemahan pupuk hijau adalah kandungan unsur haranya rendah dengan waktu pengomposan yang lama.Untuk mengatasi permasalahan tersebut pada saat ini mulai dikembangkan penggunanaan jasad renik yaitu mikro organisme lokal (MOL), yang dapat mempercepat pengomposan dan memperbaiki kualitas unsur hara yang ada.

MOL adalah cairan yang mengandung mikroorganisme (bakteri) yang berguna untuk tanaman dan kesuburan tanah seperti Rhizobium sp, Azospirillum sp, Azotobacter sp, Pseudomonas sp, bacillus sp dan bakteri pelarut phospat yang merupakan hasil produksi sendiri dari bahan-bahan alami disekeliling kita (lokal). Bahan alami tersebut merupakan media untuk hidup dan berkembangnya mikroorganisme yang dapat mempercepat penghancuran bahan-bahan organik (Amalia, 2008).

\section{Rumusan Masalah}

Berdasarkan uraian tersebut di atas dirumuskan permasalahannya adalah : pemberian pupuk hijau dan MOL berpengaruh terhadap Pertumbuhan dan Hasil Tanaman Kacang Tanah (Arachis hypogaea L.)”

\section{Tujuan Penelitian}

Penelitian ini bertujuan untuk mengetahui pengaruh jenis pupuk hijau (P) dan pemberian Mikro Organisma Lokal (MOL) terhadap pertumbuhan dan hasil tanaman kacang tanah.

\section{METODE PENELITIAN}

Penelitian Ekperimental ini dilakukan di rumah kaca menggunakan rancangan Acak Lengkap (RAL) yang terdiri dari 2 faktor yaitu Pupuk hijau (P) dan Mikro Organisme Lokal /MOL (M). Mikro Organisme Lokal $(\mathrm{MOL})$ terdiri dari $: \mathrm{MO}=$ tanpa MOL dan $\mathrm{M} 1=$ menggunakan MOL. Pupuk Hijau terdiri dari: $\mathrm{P} 0=$ Tanpa Pupuk, P1 = daun Gamal, P2 = daun Turi, $\mathrm{P} 3=$ daun Chlotalaria, $\mathrm{P} 4=$ daun Chromolaena. Kombinasi dari kedua faktor di atas menjadi 10 unit perlakuan yaitu : M0P0, M0P1, MOP2, M0P3, M0P4, M1P0, M1P1, M1P2, M1P3 dan M1P4. Selanjutnya di buat ulangan sebanyak 3 kali sehingga secara keseluruhan menjadi 30 unit percobaan. Kemudian data dianalisis statistika dengan uji keragaman (Anova) pada taraf nyata 5\%, apabila ada beda dilanjutkan dengan Uji BNJ pada taraf yang sama.

Penelitian dilaksanakan pada bulan Juli sampai Oktober 2018, meliputi pembuatan MOL, pengomposan pupuk Hijau, pengambilan tanah, pengisian pot, penanaman biji kacang tanah, pemeliharaan tanaman dan pengamatan parameter dilapangan maupun setelah panen, selama penelitian dilakukan di Fakultas Pertanian Universitas 45 Mataram, Jln.Imam Bonjol Tohpati Cakra Utara Kecamatan Cakranegara Kota Mataram. 


\section{HASIL DAN PEMBAHASAN}

Data hasil pengamatan setiap parameter yang diamati selanjutnya dianalisis statistika pada taraf nyata 5\% dapat dilihat pada Tabel 1.

Tabel 1.Data Hasil Analisis statistika pengaruh Pupuk Hijau terhadap Semua Parameter yang Diamati

\begin{tabular}{|l|l|l|l|l|l|l|l|}
\hline \multirow{2}{*}{ No. } & \multirow{2}{*}{ Parameter } & \multicolumn{6}{|c|}{ Perlakuaan } \\
\cline { 3 - 8 } & & P0 & P1 & P2 & P3 & P4 & BNJ5\% \\
\hline 1 & Tnggi Tanaman & $87,5 \mathrm{~d}$ & $99 \mathrm{~b}$ & $92 \mathrm{c}$ & $98,5 \mathrm{~b}$ & $104,5 \mathrm{a}$ & 4,36 \\
\hline 2 & Jumlah Daun & $142 \mathrm{~b}$ & $161 \mathrm{a}$ & $155 \mathrm{a}$ & $158,5 \mathrm{a}$ & $159 \mathrm{a}$ & 6,18 \\
\hline 3 & $\begin{array}{l}\text { Berat Basah } \\
\text { Brangkasan }\end{array}$ & 47,5 & 61 & 66,5 & 56 & 52,5 & - \\
\hline 4 & $\begin{array}{l}\text { Berat Kring } \\
\text { Berangkasan }\end{array}$ & $49 \mathrm{c}$ & $59 \mathrm{ab}$ & $58,2 \mathrm{bc}$ & $60,5 \mathrm{ab}$ & $67,5 \mathrm{a}$ & 9,24 \\
\hline 5 & Jumlah Biji & 50 & 52 & 43,5 & 41,5 & 53 & - \\
\hline 6 & Jumlah Polong & 31 & 30,5 & 28 & 25 & 37,5 & - \\
\hline 7 & Berat Biji & $25,5 \mathrm{~d}$ & $29,5 \mathrm{bc}$. & $32,5 \mathrm{ab}$. & $28,5 \mathrm{c}$. & $33,5 \mathrm{a}$ & 3,71 \\
\hline 8 & Berat 100 Biji & $4,615 \mathrm{c}$ & $5,8 \mathrm{~b}$ & $5,76 \mathrm{~b}$ & $5,63 \mathrm{~b}$ & $6,395 \mathrm{a}$ & 0,55 \\
\hline
\end{tabular}

Keterangan:Angka yang diikuti oleh huruf yang sama pada baris yang sama berbeda tidak nyata pada uji BNJ taraf $5 \%$

dimana: P0 : Kontrol, P1: Daun Gamal, P2: Daun Turi, P3: Daun Clotalaria dan P4: Daun Chromolena

Tabel 1 tampak bahwa perlakuan pupuk hijau memberikan pengaruh nyata terhadap berat kering biji dan 100 biji yang didukung oleh beberapa komponen dari parameter Vegetatif tanaman Kacang Tanah seperti jumlah daun tinggi tanaman dan berat kering berangkasan. Hal ini menunjukkan bahwa penambahan pupuk hijau memberikan kontribusi hara, baik hara makro maupun mikro ke dalam tanah (Nurhayati Hakim dkk., 1986).

Reaksi Tanah $(\mathrm{pH})$ hasil pengukuran pada masing-masing pot polybag menunjukkan sedang $(6,5-$ 6,6). Reaksi Tanah sangat dipengaruhi oleh jenis bahan pupuk hijau yang diberikan. Pupuk hijau dari tajuk Chromolaena dan daun Gamal menunjukkan pH lebih tinggi dari kontrol (P0). Hal ini disebabkan oleh adanya unsur-unsur basa seperti Ca dan Mg yang dikandung oleh pupuk hijau tersebut (Kasniari, 1996).

Dilihat dari potensi tanaman Kacang Tanah sebagai Leguminosae yaitu tanaman yang mampu memanfaatkan $\mathrm{N}_{2}$ (N-udara) untuk pertumbuhan dan produksinya. Hal ini akan dapat terpenuhi apabila unsur hara selain $\mathrm{N}$ dalam tanah tersedia cukup dan reaksi tanah mendukung ketersediaan hara makro maupun mikro untuk membangun Enzim yang berperan pada proses tersebut. Enzim yang terlibat mentranformasikan $\mathrm{N}_{2}$ menjadi $\mathrm{NH}_{2}$ adalah Enzim Nitrogenase. Enzim ini disusun oleh unsur makro Belerang (S) dan unsur mikro Besi $(\mathrm{Fe})$ maupun Molibdenum (Mo). Reaksi Tanah yang digunakan penelitian antara 6,5 - 6,6 . Kondisi ini sangat mendukung ketersediaan Belerang (S), Besi (Fe) dan Molibdenum (Mo). Sehingga Enzim Nitrogenase terbentuk oleh unsur S, Fe dan Mo dalam jumlah yang cukup. Selanjutnya proses transformasi $\mathrm{N}_{2}$ menjadi $\mathrm{NH}_{2}$ untuk menyusun asam-asam amino berjalan dengan baik. Menurut Nuhayati Hakim dkk.(1986) penyerapan hara yang baik untuk unsur hara makro maupun mikro adalah pada $\mathrm{pH}$ sedang yaitu sekitar $\mathrm{pH}$ 5,8 sampai dengan 6,8 selanjutnya dikatakan pula bahwa unsur S, Fe dan Mo sangat mendukung pembentukan Enzim Nitrogenase pada pH sedang.

Pemberian tajuk Cromolaena dapat meningkatkan berat biji tertinggi dengan nyata, didukung oleh berat kering 100 biji, jumlah daun dan tinggi tanaman. Hal ini disebabkan oleh tajuk Cromolaena memberikan kontribusi hara lebih banyak daripada tanaman Gamal, Turi dan Clotalaria. Menurut Yusuf dkk.., (2007) daun Gamal mengandung 1,66\% N, 0,22\% P, 2,65\% K, 1,35\% Ca dan 0,41\% Mg. Selanjutnya Umainana dkk..(2019), menyatakan bahwa daun turi mengandung berbagai unsur hara antara lain $\mathrm{N}$ $(0,58 \%), \mathrm{P}(0,04 \%), \mathrm{Fe}(0,0021 \%), \mathrm{Mg}(0,0015 \%)$ dan Kasniari (1986) menyatakan tajuk tanaman Cromolaena mengandung 46,95\% C, $1,69 \% \mathrm{~N}, 126,9 \mathrm{mg} / \mathrm{kg} \mathrm{P}, 1,163 \% \mathrm{~K}, 1,31 \% \mathrm{Ca}$ dan 0,537\% Mg, ditambahkan juga bahwa tajuk Cromolaena mengandung Kalium 12 kali lipat dari kadar Kalium pada tanaman Alang-Alang.

Melihat kandungan unsur hara Mg pada tajuk tanaman Cromolaena $(0,537 \%)$ ternyata lebih banyak dibandingkan dengan tanaman Gamal $(0,41 \%)$. Organ-organ tanaman Kacang Tanah yang dibentuk lebih bagus dan lebih banyak. Komponen tanaman yang dibangun oleh unsur $\mathrm{Mg}$ adalah inti Klorofil dengan rumus $\mathrm{C}_{55} \mathrm{H}_{72} \mathrm{O}_{5} \mathrm{~N}_{4} \mathrm{Mg}$, warna hijau tua (klorofil A) dan $\mathrm{C}_{55} \mathrm{H}_{70} \mathrm{O}_{6} \mathrm{~N}_{4} \mathrm{Mg}$ warna hijau muda (klorofil B) . 
Dengan terbentuknya klorofil yang dominan pada perlakuan pemberian pupuk hijau tajuk Cromolaena dibandingkan dengan perlakuan yang lain, maka klorofil banyak berperan pada proses Fotosintesis, sehingga hasilnya mendukung terbentuknya komponen-komponen Vegetatif seperti jumlah daun, berat kering berangkasan dan tinggi tanaman yang dominan. Selanjutnya komponen vegetatif tanaman Kacang Tanah ini mampu mendukung koponen Generatif seperti Berat kering biji dan berat kering 100 biji, sehingga berat kering biji meningkat dengan nyata dibandingkan dengan kontrol.

Pengaruh Mikro Organisma Lokal (MOL) terhadap semua parameter yang diamati pada penelitian ini dapat dilihat pada Tabel 2.

Tabel 2. Data Hasil Analisis Statistika pengaruh Mikro Organisma Lokal (MOL) terhadap Parameter yang Diamati.

\begin{tabular}{|c|l|c|c|l|}
\hline \multirow{2}{*}{ No } & \multicolumn{1}{|c|}{ Parameter } & \multicolumn{2}{|c|}{ Perlakuan } & \multirow{2}{*}{ BNJ 5\% } \\
\cline { 3 - 4 } & & M0 & M1 & \\
\hline 1 & Tinggi tanaman & $93,2 \mathrm{a}$ & $99,4 \mathrm{~b}$ & 1,905 \\
\hline 2 & Jumlah daun & $150,8 \mathrm{a}$ & $159,4 \mathrm{~b}$ & 2,75 \\
\hline 3 & Berat basah berangkasan & 197,4 & 221,6 & - \\
\hline 4 & Berat kering berangkasan & $55,0 \mathrm{a}$ & $62,5 \mathrm{~b}$ & 2,34 \\
\hline 5 & Jumlah polong & 28,40 & 32,40 & - \\
\hline 6 & Jumlah biji & 27,00 & 30,00 & - \\
\hline 7 & Berat biji & $27,4 \mathrm{a}$ & $32,2 \mathrm{~b}$ & 1,64 \\
\hline 8 & Berat 100 biji & $5,2 \mathrm{a}$ & $6,082 \mathrm{~b}$ & 0,24 \\
\hline
\end{tabular}

Keterangan:Angka yang diikuti oleh huruf yang sama pada baris yang sama berbeda tidak nyata pada uji BNJ taraf 5\%

dimana $:$ M0 = tanpa MOL dan M1= pemberian MOL

Mikro Organisma Lokal memberikan pengaruh nyata terhadap Berat kering berangkasan, Berat kering Biji, berat 100 biji, jumlah daun dan tinggi tanaman, sedangkan parameter lainnya tidak berpengaruh nyata terhadap parameter tinggi tanaman, berat basah berangkasan, jumlah biji dan polong.

Hal ini menunjukkan pemberian MOL dapat mempercepat pelapukan dan membebaskan unsur hara lebih banyak dibandingkan degan tanpa diberikan MOL. Mikrobia yang aktif mendekompossisi adalah Rhizobium sp., Azospirillum sp., Azotobacter sp., Pseudomonas sp., Basillus sp., dan bakteri pelarut pupuk Posfat. Hasil dekomposisi ini membebaskan hara lebih banyak dibandingkan dengan tanpa diberikan MOL. Selanjutnya hara yang dibebaskan dapat tersedia lebih banyak, cepat, berkualitas kemudian diserap tanaman untuk pertumbuhan dan produksinya. Menurut Suhastyo ( 2011) MOL adalah cairan yang mengandung mikroorganisme (bakteri) yang berguna untuk tanaman dan kesuburan tanah seperti Rhizobium $s p$, Azospirillum sp, Azotobacter sp, Pseudomonas sp, bacillus sp dan bakteri pelarut phospat yang merupakan hasil produksi sendiri dari bahan-bahan alami disekeliling kita (lokal). Bahan alami tersebut merupakan tempat yang baik sebagai media untuk hidup dan berkembangnya mikroorganisme yang berguna dalam mempercepat penghancuran bahan-bahan organik. Unsur hara yang disumbangkan dari bakteri tersebut di atas adalah Nitrogen (N), Fospat (P) dan Kalium (K). Selanjutnya Amalia (2008) mengatakaan MOL mengandung senyawa- senyawa yang membantu mengikat ion $\mathrm{Al}, \mathrm{Ca}$ dan $\mathrm{Fe}$ sehingga mampu meningkatkaan ketersediaan ion Fospat dalam tanah. Unsur Fospat ini berperan dalam fase generatif yaitu proses pembentukan bunga, buah dan biji.

\section{SIMPULAN DAN SARAN}

\section{Simpulan}

Dari hasil pembahasan tersebut di atas dapat disimpulkan sebagai berikut :

1. Pupuk hijau memberikan pengaruh nyata terhadap tinggi tanaman, jumlah daun, berat kering berangkasan, berat kering biji dan berat kering 100 biji, sedangkan tidak nyata terhadap parameter lainnya. Berat Biji Kacang tanah tertinggi berada pada perlakuan Cromolaena dengan peningkatan sebesar 31,37\% (33,50 g) selanjutnya semakin kecil diikuti oleh daun Turi 27,45\% (32,50 g), daun Gamal 15,69\% (29,50g), Chlotalaria 11,76\% (28,50g) dibandingkan dengan tanpa Pupuk hijau (25,5g). 
2. Mikro Oganisme Lokal memberikan pengaruh nyata terhadap tinggi tanaman, jumlah daun, berat kering berangkasan, berat kering biji dan berat kering 100 biji. Berat kering biji perlakuan Mikro Organisma Lokal meningkat 14,90\% (32,2 g) dibandingkan tanpa Mikro Organisma Lokal (27,4 g).

\section{Saran-saran}

Perlu dilakukan penelitian lebih lanjut mengenai pupuk hijau dan Mikro Organisme Lokal terhadap pertumbuhan dan hasil pada tanaman kacang tanah ( Arachis hypogeae L.) dengan berbagai dosis pupuk dan saat pemberian MOL.

\section{DAFTAR PUSTAKA}

Amalia, A, 2008. Pembuatan Starter/MOL (Mikro Organisme Lokal) oleh Petani. http://organicfield.wordpress.com. (Diakses pada tanggal 1 Februari 2018).

Damanik, J. 2009. Pengaruh Pupuk Hijau Krinyu (Chromolaena odorata L.) Terhadap Pertumbuhan Dan Produksi Jagung (Zea mays L.).USU Repository. Sumatera Utara.

Jusuf, L. 2006. Potensi Daun Gamal Sebagai Bahan Pupuk Organik Cair Melalui Perlakuan Fermentasi. Jurnal Agrisistem., Vol. 2 No. 1.

Jusuf, L., Mulyati A. M., A. H. Sanaba. 2007. Pengaruh Dosis Pupuk Organik Padat Daun Gamal Terhadap Tanaman Sawi. Jurnal Agrisistem., Vol. 3 No. 2

Kasniari D.N., 1996. Peranan Chromolaena Odorata dalam Meningkatkan Kesuburan Tanah pada Lahan Alang-Alang. Tesis Program Pascasarjana Unibraw. Malang.

Nurhayati Hakim, Y. Nyakpa, A.M Lubis, S.G.Nugroho,M.R.Saul, A.M.Diha, Go.Ban Hong dan H.H Bailey .1986. Dasar-Dasar Ilmu tanah. Universitas Lampung. Lampung.

Parnata, Ayub S. 2004. Pupuk Organik Cair Aplikasi dan Manfaatnya. Agromedia Pustaka. Jakarta 112 hal.

Suhastyo, A A. 2011. Studi Mikrobiologi dan Sifat Kimia Mikroorganisme Lokal yang Digunakan pada Budidaya Padi Metode SRI (System of Rice Intensification). Tesis Pascasarjana Institut Pertanian Bogor. Bogor.

Suprapto, 2001. Bertanam Kacang Tanah. Penebar Swadaya. Jakarta.H 33.

Tim Bina Karya Tani, 2014. Pedoman Bertanam Kacang Tanah. Yrama medya. Bandung. H 9.

Umainana M.R.,A.S.Mubarak dan E.D Masithah. 2019. Pengaruh Konsentrasi Pupuk Daun Turi Putih (Sesbania grandiflora) terhadap Populasi Chlorella Sp.Journal of Aquaculture and Fish Health. Vol.8. no.1.

Vyan RH. 2009. http://vyanrh.wordpress.com/2009/08/03/kacang-tanah-manfaat-dan-dampaknyal. Diakses tanggal 4 Februari 2018 